\title{
Negotiating empowerment: Women and identity in Nigeria
}

\author{
Omobolaji Ololade Olarinmoye
}

Department of Government, Hamilton College, NY, USA.

Accepted 19 March, 2013

\begin{abstract}
This paper focuses on Women's empowerment within the context of identity mobilization in Africa using as case study the leading Muslim women's association in Nigeria, Federation of Muslim Women Association of Nigeria (FOMWAN). It argues that Muslim women have been able to create an opening for themselves within the structure of Islam in Nigeria in recent times through the use of the discourse of Islamic reform but that such discourse of reform displays contradictions which opens it to being used as a source of legitimacy by more extreme fundamentalist actors with negative impact on the goal of women's empowerment.
\end{abstract}

Key words: Islamic, identity, Nigeria, women, Muslim.

\section{INTRODUCTION}

A key feature of women's lives in the Global South is the quest for empowerment, a departure from the present disadvantages that characterize their everyday lives. Empowerment "refers to the enhancement of an individuals or group's capacity to make choices and transform those choices into desired actions and outcomes" (Alsop and Heinsohn, 2005:5). The capacity to make an effective choice is primarily influenced by two sets of factors: agency and opportunity structure. Agency is the ability to make meaningful choices while the formal and informal contexts (laws, regulatory frameworks, and norms governing people's behavior) within which actors operate makeup the opportunity structure (Alsop and Heinsohn, 2005:6).

Of the 1.3 billion people who suffer absolute poverty worldwide, $70 \%$ are women. Women work $2 / 3$ rds of the world's working hours but earn only $10 \%$ of the world's income and own less than $1 \%$ of the world's property. They also make up 2/3rds of the estimated 876 million adults worldwide who cannot read and write. The disadvantage faced by women is also generational as girls make up $60 \%$ of the 77 million children not attending primary school globally (Care, 2005:1).

For African women, the picture of disempowerment is worse. On a scale of indices of empowerment developed by the World Economic Forum, African women have some of the lowest scores (Lopez-Claros and Zahidi, 2005:9). As the scales cover the key indices of human development: economic participation; economic opportunity, political empowerment; educational attainment and health and wellbeing-, the low rating of African women translates immediately into grave limitations in their wellbeing.

The limitations in wellbeing of women are shared by the majority of people in Africa as shown by the ranking of African states on the UNDP Human Development Index of 2009 (HDI, 2009). It means that in terms of life expectancy, literacy, education and standard of living, the majority of Africans are living in hell with women located in the deepest of the pits of hell because there is very little hope for change in their situation, given the weak nature of the African state, its incapacity to provide basic social services and its disadvantaged situation in the current process of globalization. 
The low developmental capacity of the State in Africa is matched by an over-developed capacity for violence and coercion, which is deployed to suppress free expression of demands by citizens for changes in their low development status and to engage in search for political alternatives that encourage human development.

In the absence of viable and democratic voice structures such as political parties and civil society organizations, periodic demands by disadvantaged groups for greater control of their political, economic and social destinies have been pursued through the mobilization of religious, ethnic and political identity (Osaghae and Suberu, 2005). In other words, identity mobilization has come to the fore as a mechanism for pushing the state to face and assure its developmental responsibilities.

It thus means that in order to be successful, women's empowerment has to take into consideration the fact that the context of developmental empowerment is currently structured by identity factors, more so as identity mobilization movements place high premium on women in their activities. For ethno-religious movements, "Women, their roles, and above all their control, are at the heart of the fundamentalist agenda. That they should conform to the strict confines of womanhood within the fundamentalist religious code is a precondition for maintaining and reproducing the fundamentalist version of society" (Sahgal and Yuval-Davis, 1992).

Similarly as it concerns ethno-nationalist movements, "Women are the bearers not just of children in the abstract, but of children who will grow up to be members of the ethnic group. So it is through controlling women that ethnic boundaries (core values) can be kept in place and overtime demarcates the junction between internal cohesion and external difference" (Wilson and Frederickson, 1995).

The question in relation to women's empowerment in Africa is whether the importance placed on women by identity mobilization groups translates into their empowerment? For some analysts, the answer is no because the centrality of women results not from "a desire for their empowerment \& equality but from a quest to construct static, homogeneous and exclusionary identities for a political agenda which is to forge absolute power through the assertion of identities, to enforce compliance and close spaces for debates and dissent" (Madhu, 2008).

In other words, for women generally and for African women specifically, identity movements do not provide the opportunity-agency couple that favor their empowerment or provide them with much possibility to make choices andtransform such into desired actions and outcomes.

The emergence of Islamic feminism which argues for the "claiming of rights by women from within the framework of Islam" challenges the view of identity movements as hostile terrain for women empowerment. So what is the reality of empowerment for women in African identity movements? What do they really represent or foster for women in Africa? Do or can women challenge successfully the power structures within identity movements that the uses women as central actors in the ideological reproduction of the collectivity and as transmitters of its culture?

Focusing on Nigeria, a country synonymous with high ethno-religious identity mobilization activities and specifically, the foremost Muslim women's organization in Nigeria, the Federation of Muslim Women Associations of Nigeria (FOMWAN) this paper addresses the question of whether the spaces created by identity mobilization (Islam) really represent or foster women's empowerment in Africa.

It argues that Muslim women have been able to create an opening for themselves within the structure of Islam in Nigeria in recent times through the use of the discourse of Islamic reform but that such discourse of reform displays contradictions which opens it to being used as a source of legitimacy by more extreme fundamentalist actors with negative impact on the goal of women's empowerment.

The paper is in three sections. Section one situates Muslim women reform discourse within the broader context of Islamic reform discourse. Section two examines the discourse of Muslim women's reform produced by FOMWAN in two dimensions, the formal (statutes, laws and objectives as contained in the handbooks of FOMWAN) and informal (speeches, interviews, seminar papers) produced by past and present FOMWAN executives (Amirah/NaibatulAmirah). While Section three analyses the constitutive dynamics of FOMWAN "two phase" discourse and its consequences for women's empowerment and development in the Nigerian Muslim community.

The methodological approach followed is qualitative drawing upon information collected during fieldwork for a project on Faith and Accountability in International Development in January 2010 and January to February 2011 and on secondary sources on women's empowerment and Islamic feminism and Islamic reform in Nigeria. Textual analysis of the constitution and public pronouncements of key leaders of FOMWAN was also deployed.

\section{MUSLIM WOMEN REFORMERS AND THEIR DISCOURSE OF WOMEN'S EMPOWERMENT}

A discourse is a group of statements that provides a language for talking about; a way of representing the knowledge about a particular historical moment. Discourse refers to systems of statements, which constructs an object. Muslim women reformers have developed a system of statements for representing and articulating their quest for women's empowerment the key element of which is "the claiming of rights from within 
the framework of Islam". Such claiming is possible because "Islam displays several aspects that serve their (women's) purpose when it comes to articulating the meaning of women's rights, gender inequality and social justice (Afshar, 1994).

Specifically, it is argued, Muslim women are empowered by Islam as Islamic dictum bestows complementarity on women as human beings, as partners to men and as mothers and daughters. Islam demands respect for women and offers them opportunities to be learned, educated and trained while at the same time providing an honored space for them to become mothers, wives and home makers. Islam also recognizes the importance of women's life cycles as it gives them different roles and responsibilities at different times of their lives and at each and every stage honorsand respects them for that which they do. Islam also provides women with exemplary female role models such as Fatima, Prophet Mohammed's daughter and wife to Imam Ali, both of whom have delineated a path that can be honorably followed at each stage of growth of the Muslim woman.

Most important for Muslim Women reformers is the fact that the first feminist of Islam was the prophet Mohammed himself. During his prophet-hood, many reforms concerning the treatment and place of women were instituted. They include efforts to: abolish female infanticide, to allow women to possess and implement full control over their wealth and guarantee women the right to inherit and bequeath property. Strict limits were also placed on polygamy and women were allowed to keep their dowry (Arshad, 2008).

The discourse of Muslim women reformers is framed within the broader context of the Islamic reform movement. Islamic reform is conceived as the "survival strategy adopted by religious and secular systems during their moribund and weak periods, when they are forced to undergo internal and external reconstitution in order to strengthen and consolidate their hold and retain relevance in a fast changing society" (Bako 2004:2). Islamic reform is seen to involve the retaining of the fundamental belief system and practices of Islam; discarding elements deemed unnecessary, borrowing from rival religions and manipulating their weaknesses, rejecting, fighting and withdrawal from dominant systems and undergoing internal renewal and invigoration through the revival of their golden age (Bako, 2004:3).

For Islamic reformists, reform signifies a revival, a return to sources of Islam to regain a purified vision, long since lost in the mire of worldly governments. They argue that reform, a return to the roots and recapturing of both the purity and the vitality of Islam as it was at inception is necessary because Islam is a total and comprehensive way of life and religion is integral to politics, law, and society.

The failure of Muslim societies is argued to be due to their departure from the straight path of Islam and their following a western secular path, with its secular, materialistic ideologies and values. For the restoration of God's rule and inauguration of a true Islamic social order civil codes modeled on western principles must be replaced by Islamic law, which is the only acceptable blueprint for Muslim society.

The reform process in Islam is thus for Muslim women reformers, an opportunity to create a space of freedom for themselves within what is essentially a system hostile to women. The reform process enables them to advance claims that: women constitute a special category constructed by Islam; female demands have to be confined within the boundaries set up by religious tradition and the legal, theological and political frameworks it establishes; Islam is open and flexible, allowing women a space to engage in negotiating their rights.

Such claims encourage the rise of a new type of Islamic woman with new characteristics that are distinct from the image of the domesticated woman promoted by non-reformist or traditionalist Islamic clerics. Thus for Muslim women reformers, the goal of Islamic reform of returning to a golden age of Islam is a good one as it gives reason for optimism and much room for maneuver for women. The room to maneuver provided by Islamic reform is reinforced by its emphasis on the right to individual interpretation of the Quran and the Sunna or ljtehad (independent reasoning) which permits women rights to (re)-interpret Islamic law and challenge dominant patriarchal interpretations that dis-empower women.

Briefly put, the empowerment discourse of Muslim women reformers involves undermining the clerical agenda both within and outside the Islamist framework in a number of ways:

(i) "By subtly circumventing the dictated rules (e.g., reappropriating the veil as a means to facilitate social presence rather than seclusion, or minimizing and diversifying the compulsory hijab and dress code into fashionable styles),

(ii) Engaging in a feministic ijtehad, emphasizing the egalitarian ethics of Islam, reinterpreting the Qur'an, and deconstructing Sharia-related rules in a women-friendly egalitarian fashion (e.g., in terms of birth control, personal status law, and family code to the extent of legalizing a demand for wages for housework).

The strategy and praxis of the discursive movement of Muslim women reformers, which is primarily scriptrelated, has been adapted by different reform actors to specific and local contexts to produce three principal variants: Islamic Feminism, Muslim Feminism and Islamist Feminism (Fazaeli, 2006).

Islamic Feminism; refers to "a movement of women who have maintained their religious beliefs while trying to promote egalitarian ethics of Islam by using the femalesupportive verses of the Qur'an in their fight for women's 
rights, especially for women's access to education (Chamas, 2009; Moghadam, 2002, 27).

Muslim Feminists adopt a liberal view of Islam and try to adapt it to modern times. Muslims feminists argue that for a long time, the Islamic imagination has been dominated by a patriarchal vision of Islam but that such is not necessarily the authentic Islam. They propose as solution a primarily focus on the teachings of the Koran because much of hadith and Sharia is a patriarchal reading of Islam. Muslim feminists point out that a liberal and feminist review of the Koran could contribute to the development of women's emancipation in the Islamic country (Darvishpour, 2003). Very good examples of Muslim Feminist organizations are the Trans-national Muslim Women's network, Women Living under Muslim Laws (WLUML).

Islamist Feminists: are advocates of political Islam. They view the teachings of Islam as their champion and supporter. The prescriptions that are found in the Qur'an and in anecdotes from the life of the Prophet Mohammed are regarded as the paradigm to which modern Muslim women wish to return. The source of impediment to the progress experienced today by Muslim women today lies not in Islam but in alien ideological intrusions into Islamic societies, ignorance and distortion of the true Islam or exploitation by individuals within society (Arshad, 2008:2).

The three variants of the Muslim women's reform project reflect a continuum of identities for women possible within Muslim societies. As argued by Cooke (2004, 94):

"The Islamic identification connotes another form of achieved identity, one which is highly volatile and contingent. "Islamic" bridges the two poles of Muslim and Islamist identifications. It describes a particular kind of self-positioning that will then inform the speech, or the action, or the writing, or the way of life adopted by someone who is committed to questioning Islamic epistemologyas an expansion of their faith position and not a rejection of it".

\section{MUSLIM WOMEN'S REFORM IN ACTION: THE FEDERATION OF MUSLIM WOMEN ASSOCIATION OF NIGERIA (FOMWAN)}

FOMWAN is one of the largest Muslim women's organizations in Africa. It is a federation of over 500 affiliates across Nigeria established in 1985. It lays emphasis on the improvement of the lives of Muslim women and children in particular and Muslims in general through the provision of social services to Muslim women and families through its primary schools, HIV/AIDS and Reproductive Health Education Programme and training of Traditional Birth Attendants. It also plays an active political role through participation in election monitoring (state and presidential elections).

FOMWAN is an Islamic NGO. Like all Islamic NGOs it provides relief and humanitarian assistance to poor communities during emergencies, natural disasters (prolonged drought and floods), famine and epidemics. It is also engaged in long-term development activities, including community development, agriculture, water, health and education in the least-developed Muslim societies in Nigeria. Like other Islamic NGOs FOMWAN distinguishes itself from other NGOs (secular) by the fact that "voluntarism is a religious duty in Islam, and claims also to be advancing a Muslim way of life and expanding the Islamic umma (community) worldwide" (Salih, 2002).

FOMWAN women's reform discourse exists in two forms Formal and Informal. The Formal discourse is contained in the statutes, laws and objectives as found in the handbooks of the organization especially its publication titled "The Rights and Responsibilities of Muslim Women" published in 2000.

FOMWAN's objectives are clearly reformist as they seek to promote understanding and practice of the teachings of Islam, encourage Muslim women to establish groups throughout the country for educational purposes, establish a framework for national cooperation and unity among women Islamic associations, provide a forum for Muslim women's views to be expressed at national and state levels.

Furthermore, the objectives are to be promoted through peaceful persuasion propagated through coordination of activities of existing Muslim women organizations, encouraging such organizations where such does not exist, developing a national curriculum/guideline for women and children Islamic education, organizing congresses, through suitable literature for Muslim women and children and maintaining contact with the state and federal governments and press as spokespersons for Muslim women in all matters affecting them and most importantly through protection and promotion of the rights of Muslim women and children.

Women's rights under Islam to be protected include: general rights, to life, worship, education, self-respect, to choose husband, fair treatment in marriage, divorce and expression; economic rights: right to a dower, maintenance in matrimony, right to property, to enter into contract, to have a will, to inherit, to have a job and engage in economic activity; politicalrights, right to political view, to participate in politics and to vote and difficult circumstances rights that include for a divorcee, right to shelter, to dower, to maintenance, support during maternity. For widows, rights under this category include, rights to maintenance, not to be inherited and right to remarry. Muslim women Refugees have right to remarry and political rights.

Informal Discourse is used to refer to the public speeches/papers of FOMWAN's leadership. The base 
paper to be used in the analysis of informal discourse of FOMWAN's leaders is that of Alhaja Okunnu delivered at the "Conference on Sharia in Nigeria", London, 2001, April. It is the clearest articulation of the actions and objectives of FOMWAN by its leadership that we came across. The fact that with the views expressed in the paper resonates in the speeches and newspaper articles written by other senior members of its executive such as Bilikisu (2002) and Adekola (2005) leads us to conclude that the views of Alhaja Okunnu are not personal but an expression of the ideals and opinions of the group's leadership.

Again, the reformist agenda of FOMWAN comes out clearly in the title of Alhaja Okunnu's paper "Women, Secularism and Democracy: Women's Role in the Regeneration of Society (2001) which she interpreted as "The Role of Women in Islamic Re-awakening". She defines Re-awakening as "a battle to re-instate Islamic values above secular values". In other words FOMWAN, like all Islamic reform movements, subscribes to the diametrical opposition and incompatibility between Secularism defined as "Westernization" and Islam.

Secularism is seen as negative as it "replaces reference to God with a meaningless term "Nature" and sees the goal of life as "mutual well-being, life of ease, pleasure and power". Briefly secularism is about "Godlessness". On the other hand Islam is about "morality" and so superior because it creates a person whose life revolves around the "Unity of God". The Muslim community is thus the best because it ran on Islamic principles taught in the Koran and Sunnah of the Prophet Mohammed.

The lack of morality and its associated values endemic to secularism is seen as the cause of societal degeneration as modern nations such as Nigerians "are guided by man-made ideologies" such as "Democracy". Democracy which is defined as government of the people for the people and by the people "is a product of secularism and distinctly un-islamic as it has no reference to Allah, though power is held in trust for Allah and his will manifested in the Sharia is the real source of all Sovereignty". But Islam is not anti-developmental because unlike Christianity that was an instrument of colonialism, Islam was a "tool of decolonialization and reaffirmation of morality in community life".

Having established the superiority of Islam and apportioned the blame for society's degeneration on secularism, Alhaja Okunnu goes on to discuss FOMWAN's efforts at "reinstating Islamic values above secular values" through its educational, social and moral development programmes. Through its Tarbiyah Programme, FOMWAN aims at providing the means to protect Muslim children and adolescents from indiscriminate mixing with non-Islamic surroundings.

FOMWAN's Youths Programme focuses on insulating young men and especially young women form the glamour and decadence of "Jahiliyah" society through the actions of groups such as the "Movement for Islamic Culture and Awareness" whose target population are those Muslims "who do not readily identify with the religion, Muslim who have little or no exposure to Islamic teachings and Muslims who are generally seeking a better understanding of Islam.

Based on its fundamental opposition to secularism, FOMWAN sees "Sex education" as by the state as "Secular/ Sexualist" in nature and orientation and encouraging of "infidelity and Promiscuity" because its goal of teaching the youth about their bodies, how to respect each other, how to abstain from sex and protect themselves if they decide to have sex is un-Islamic. It therefore argues, "Sex education should be handled by family members or professionals in the field of medicine, preferably members of the same sex" (Okunnu, 2001).

Finally FOMWAN argues for complementarity of males and females in Muslim societies and supports such with quotes from the Koran. It views the man as the head of the family and breadwinner while the woman's primary responsibility is the home and the family because "the mother is a school. If she is a bad school she will turn out bad children unto society and if she is a good school her children will be assets to society". Therefore FOMWAN through a combination of religious education and functional literacy seek to inculcate the virtues of Islamically defined statutes of the woman in its members especially the re-orientation of educated sisters from western culture which is antithetical to true Islamic culture. Its goal is to "attain the standard set in the time of the Holy Prophet".

One key issue comes out clearly from the analysis of FOMWAN discourse: it presents two public faces, the first is an "Islamic feminist" one (formal discourse) while the other is "Islamist" (Informal discourse). The impact of the two faces of Muslim women'sreform discourse on women's empowerment in Islam comes clearly when examined within the context of the implementation of the Sharia code in Northern Nigeria.

The Sharia campaign claims to protect the interest of the poor and the vulnerable in society such as the old, the young and women but as argued by BAOBAB (2003:3-4).

"Those who have been charged under the new Sharia Penal Codes have been predominantly poor, often rural but also the urban poor, non-literate women, men, and children. It is clear that women more often than men are prosecuted for zina, despite the fact that adultery, fornication and "immoral gatherings" require (at least) two people - one of each sex. Although both women and men have been found guilty of fornication and consequently whipped (and/or imprisoned, if men), only women have been convicted of adultery, with its higher penalty of stoning to death"

More specifically, Women's rights have been extensively 
violated under the new Sharia code in Nigeria. Pressure is high for the removal of sexuality education school curricula. Several attempts have also been made to prevent non-governmental organizations (NGOs) from running sexuality education workshops (on family planning and reproductive health care, for example).

The father's right to control the marriage of a nevermarried daughter (ijbar) is being re-asserted, and child marriage is being advocated again. Women's right advocates have also suffered criticisms, abuse, verbal attacks and physical threats to women's rights activists measures meant to intimidate, and which, if successful, would further hinder the implementation and advocacy of women's rights issues.

Quite apart from the texts of the laws, cases of discriminatory implementation and improper procedures that vitiate women's rights in particular have occurred. For example,

"By postulating that pregnancy outside marriage is evidence of zina (a minority position in Sharia which is not held by the Hanafi, Hanbali and Shafi schools, nor a variant of the Maliki school), women have been held to a different standard of evidence than have men. Nonmarried women are required to provide evidence to prove their innocence, but men are not. If the prosecution does not provide independent evidence, such as four eyewitnesses, men can simply walk away, unlike women. This is without respect for the prescription in the Qu'ran, which specifies that whoever brings an allegation of zina without four witnesses, be they male or female, will themselves be guilty of bearing false witness and subject to punishment. More women than men have been both charged and convicted of zina (Baobab, 2003, 8)."

The actions of northern state governments since the beginning of the implementation of the new Sharia code in Nigeria has specifically targeted the objectives of FOMWAN as enumerated in its formal discourse and received support tacitly or otherwise from the informal discourse propagated by FOMWAN's leadership as reflected in the paper of Alhaja Latifat Okunnu.

\section{THE TWO FACES OF MUSLIM WOMEN'S REFORM DISCOURSE AND WOMEN'S EMPOWERMENT}

It is exactly the ambiguity in the discourseof Muslim women reform that its critics emphasize. Haideh (1998:42) complains that:"it has become fashionable to speak sympathetically and enthusiastically about the reformist activities of Muslim women and to insist on their independence of thought. . . The message is that a new road has been opened up for women-Muslim and nonMuslim alike-to gain equal rights to men: a road based on feminist interpretations of Islamic Sharia laws"

For radical critics of Muslim women's reform project, any reform movement or discourse that is carried out within the framework of Islamic law and that takes for granted the legitimacy and permanence of an Islamic state and of Quranic edicts is at best a very limited project and at worst a way of legitimizing the Islamic legal, political, and moral framework.

For them, No reform is possible in an Islamic legal and political system where "the very structure of power is male dominated to an absolute degree, backed by the Constitution, an all male clerical system ruling the country, and a Sharia written for an era long past its sellby date" (Kia, 1994: 20-21). Radical critiques argue that Islamic reformist discourse is not identical to liberation theology but derives from a religion in which the role of women is clearly stated. This stated role includes women's inferior status with respect to marriage, divorce, child custody, inheritance, and court witnessing, the ban on women judges, and mandated veiling.

They also disapprove of the argument that veiling, domesticity, and dedication to Islamic principles can be interpreted as signs of free agency, self-determination and identity construction when undertaken by women who are not succumbing to societal and political pressure (Kia, 1994:20-21). In other words, attempts to reinterpret the Quran and to restructure Sharia law are useless due to the power of orthodox interpretations of Islam (Chamas, 2009: 248)

Thus critics of the reform project argue that by working within the framework provided by Islamic Reform, Muslim Women reformers are involved in crafting a discourse of Islamic reform marked "more by opacity than transparency", which permits Islamic fundamentalists to acquire a level of legitimacy that is astounding. Working through activities that are simultaneously liberating and oppressive, Islamic fundamentalists, operating through Islamic feminism are able to attract and gain legitimacy with audiences, western and national, that would otherwise not touch it with a hundred foot pole.

What thus results from the contradictions in the two faces of FOMWAN is a limitation in its ability to effectively act as a bulwark for protecting the rights of Muslim women within Islamic reform action and in extension a limit to the ability of Muslim women's reform to empower women within Islam.More importantly is the fears it raises of Muslim women reform becoming a means of legitimizing Islamic reform with the international development community while helping the international development community overcome criticisms of its inability to engage with and empower women within Islamic communities especially after September 11, 2001 bombings of the twin towers in New York.

According to Duval (1997) Muslim women are thus involved in "an ambiguous political struggle" where they are on the one hand fighting actively against their inequality, but on the other are accepting or supporting their own subordination". The ambiguity of the reform program of Muslim women is recognized and acknowledged by its supporters who argue that the ambiguity is actually a plus to the movement. 
Islamic feminists such as Mahmoud (2005) recognize that the fact that Muslim women in order to assert themselves in what have traditionally been male-centric arenas have had to deploy the very rhetoric that stems from discourses that have traditionally justified their submission to male authority is problematic but she argues that by attempting to exercise free agency within a system of subordination, "women resist the dominant male order by subverting the hegemonic meanings of cultural practices and redeploying them for their "own interests and agendas" (Mahmoud, 2005:6).

For Cooke (2000: 93), Islamic Feminism as an expression of:

"A double commitment: to a faith position on the one hand, and to women's rights both inside and outside the home on the other. The label Islamic feminist brings together two epithets whose juxtaposition describes the emergence of a new, complex self-positioning that celebrates multiple belongings. To call oneself an Islamic feminist is not to describe a fixed identity but to create a new, contingent subject position. This location confirms belonging in a religious community while allowing for activism on behalf of and with other women. This linking of apparently mutually exclusive identities can become a radical act of subversion."

The two faces of FOMWAN might be a reflection of the federal nature of FOMWAN as an association uniting several disparate Muslim women's organizations but it can be argued that they are simultaneously liberating and limiting for the emancipation goal of women within Islam. On the one hand, the Islamic feminist face enables women in Islam to fit into and tap benefits accruing from a broader discourse of empowerment through human rights and development propagated by international development community while the Islamist face enables FOMWAN to have legitimacy within the Islamist reform movement in Nigeria (and its political agenda) and legitimately claim to be the umbrella body for Muslim women's organizations in Nigeria.

On the other hand, the Islamic feminism facet is limited in its ability to tap into the empowerment benefits associated with development discourse by the Islamist facets radical opposition to all things secular and its desire for creation of a distinct Islamic society opposed to such secularism.

\section{CONCLUSION}

What a study of FOMWAN's discourse shows is that the Muslim reform project does not provide, as it is otherwise argued by its proponents, freedom to be autonomous and self-defined or truly liberated, which is the actual objective of women's empowerment. Rather what it does is to create a small fragile space of empowerment within the context of Islamic reform in Nigeria with such cautious empowerment being susceptible to reversals because of the contradictions inherent in the two faces of its public discourse.as the case of the reversals Muslim women's rights since the introduction of full Shari 'a legal system in northern Nigeria.

\section{REFERENCES}

Adekola A (2005). Role of Religious Organizations in Poverty Alleviation among the Muslim Ummah. Paper presented at the Workshop on Poverty Alleviation, Ibadan. Development Policy Center June 9.

Afshar H (1994). Women and the Politics of Fundamentalism in Iran. Women against Fundamentalisms J. 5:15-20.

Alsop R, Heinsohn N (2005). Measuring Empowerment in Practice: Structuring Analysis and Framing Indicators. World Bank Policy Research Working Paper. No. 3510. February: p.123.

Arshad H (2008) Islamic Feminism and the Role of UNESCO. George Washington University EDUC 228, $28^{\text {th }}$ April.

Bako S (2004) "The Islamic Reform Movement and its Transnational Dimension: A Study of Yan Izala, Yan Shia and Yan Islamiyya in Northern Nigeria" In: Fourchard, Laurent (Ed.) Transnational Religious Actors and Networks in West Africa, Ibadan. IFRA

BAOBAB for Women's Human Rights (2003). Sharia Implementation in Nigeria: The Journey So Far. Lagos.

Bilikisu Y (2002). Women and Empowerment in Islam. Weekly Trust, Nigeria.

CARE (2005). Women's Empowerment, http://www.care.org/newsroom/ publications/whitepapers/woman_and_empowerment.pdf. Accessed 8/6/12.

Chamas S (2009). Sayyid Muhammad Hussein Fadlallah: Muslim Cleric and Islamic Feminist, J. Altern. Perspect. Soc. Sci. 1(2):248.

Cooke M (2000). Multiple Critique: Islamic Feminist Rhetorical Strategies. Nepantla: Views from South. 1:1. Duke University Press.

Darvishpour M (2003). Islamic feminism: Compromise or Challenge to Feminism? Iran Bulletin- Middle East Forum, Summer.

Fazaeli R (2006). Contemporary Iranian Feminism: Identity, Rights and Interpretations" Paper Presented at AMSS 35th Annual Conference Muslim Identities: Shifting Boundaries and Dialogues, October 27-29.

Haideh M (1998). Women, Modernity, and Political Islam. Iran Bulletin 19-20 Autumn/Winter.

Human Development Index 2009

Kia M (1994). The Limits of Islamic Feminism, Iran Bulletin. 8 JanuaryMarch

Lopez-Claros A, Zahidi S (2005). Women's Empowerment: Measuring the Global Gender Gap. Geneva. World Economic Forum, Geneva.

Madhu M (2008). Fundamentalisms in Asia-Pacific: Trends, Impact, Challenges and Strategies Asserting Women's Rights. Thailand. Asia Pacific Forum on Women, Law and Development.

Mahmoud S (2005) Politics of Piety: The Islamic Revival and the fFminist subject. Princeton: Princeton University Press.

Moghadam VM (2002). Islamic feminism and its discontents: Towards a resolution of the debate. In: Allen C, Howard JA \& Salib T (Eds.), Gender, politics, and I.

Okunnu L (2001). Women, Secularism and Democracy: Women's Role in the Regeneration of Society, Conference on the Restoration of Sharia in Nigeria- The Benefits and Challenges. The Nigeria Muslim Forum (UK) 2001, April.

Osaghae EE, Suberu RT (2005). A History of Identities, Violence and Stability in Nigeria, Centre for Research on Inequality, Human Security and Ethnicity (CRISE). CRISE Working Paper. Univ. Oxf. p.6

Salih M (2002). "Islamic NGOs in Africa: The Promise and Peril, Occasional Paper, Center for African Studies, University of Copenhagen.

Sahgal G, Yuval-Davis N (1992). Refusing Holy Orders: Women and Fundamentalism in Britain. London. Women Living Under Muslim Laws: International Solidarity Network.

Wilson J, Frederickson N (1995). Phonological awareness training: An evaluation. Educational and Child Psychology 12(1):68-79. 